\title{
Efficiency improvement of the hot blast generating system by waste heat recovery
}

\author{
Pei-Hsun Lin, Pai-Hsiang Wang, Hui-Tien \\ Chen \& Wei-Lun Chung \\ Energy and Air Pollution Control Section, New Materials Research and \\ Development Department, China Steel Corporation, Kaohsiung, Taiwan
}

\begin{abstract}
To meet the increasing demand for energy saving and sustainable $\mathrm{CO}_{2}$ reduction, a heat-pipe heat exchanger has been applied in the hot blast generating system to recover the flue gas sensible heat for the purpose of fuel gas preheating. In this paper, the performance evaluation method for the hot blast generating system is proposed and used to investigate the fuel gas preheating effect on the system's thermal efficiency. Experimental observation revealed that $3.1 \%$ of the efficiency improvement was achieved by the application of waste heat recovery. Accordingly, the energy consumed to enhance the blast air temperature was diminished by $0.115 \mathrm{~kJ} /{ }^{\circ} \mathrm{C}-\mathrm{Nm}^{3}$. In addition to energy saving, the fuel gas preheating also led to the reduction of the enrichment gas depletion rate. Based upon the field test results, the records indicated that the implementation of the flue gas heat recovery scheme in the hot blast generating process resulted in a saving of fuel consumption by $822 \mathrm{l} / \mathrm{h}$ on an oil equivalent basis. The benefits of energy saving over 1.9 million US dollars and the $\mathrm{CO}_{2}$ reduction 15,000 tons can be achieved annually.
\end{abstract}

Keywords: waste heat recovery, hot stove, energy saving, thermal efficiency.

\section{Introduction}

Hot stoves are thermal regenerators applied to produce hot blast air in blast furnace iron making process. In China Steel Corporation, the hot blast air generating system for the No.2 Blast Furnace consists of four hot stoves. Each stove is operated alternatively with on-gas and on-blast cycles to deliver stable hot blast air flow to blast furnace under specific conditions. During the on-gas 
cycle, the fuel is burned in the combustion chamber to heat up the refractory bricks. The main fuel used for hot stove combustion is the Blast Furnace Gas (BFG), which is enriched with Coke Oven Gas (COG) in order to get the required brick temperature. With the completion of the on-gas cycle, the system proceeds to the stove change stage to purge the flue gas. Thereafter, it switches to the on-blast cycle. The on-blast cycle is the hot blast generating cycle, in which, the heated refractory bricks serve as the heat source to enhance the temperature of the cold blast air that is blown through the hot stove. The process flow diagram is illustrated in Fig. 1.

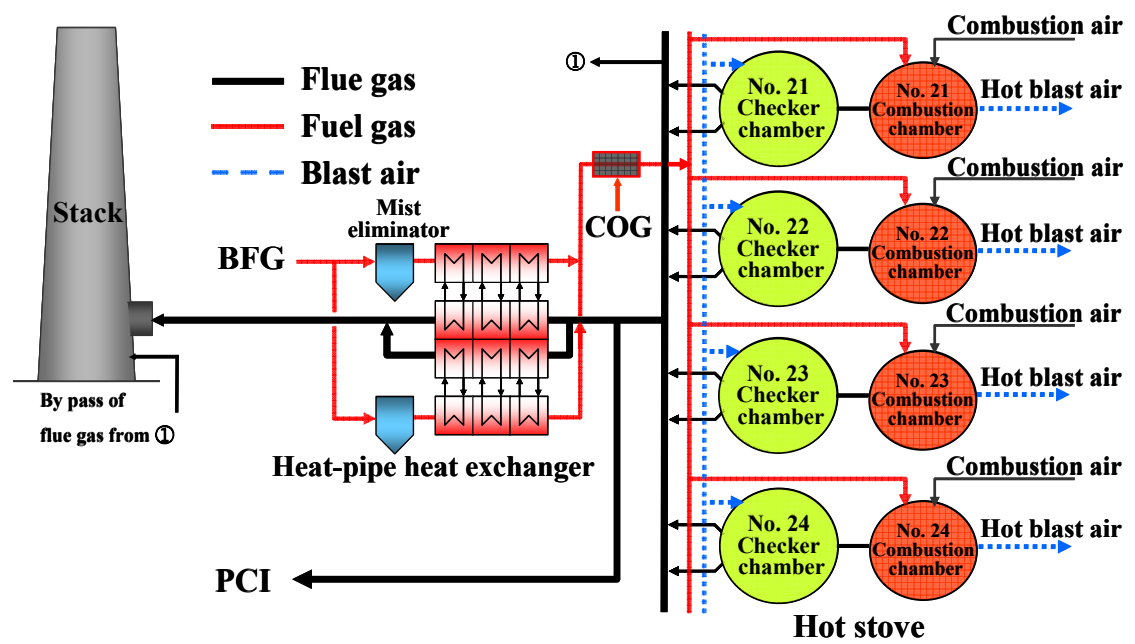

Figure 1: Process flow diagram of the hot blast air generating system.

The flue gas exhausted from the hot stoves is approximately $250,000 \mathrm{Nm}^{3} / \mathrm{h}$ at a temperature of around $260^{\circ} \mathrm{C}$. According to the original engineering design, around $20 \%$ of the flue gas was recycled to the Pulverized Coal Injector (PCI) for coal preheating, and the remaining part of the flue gas was discharged to the atmosphere via the stack. To increase the process energy efficiency, a waste heat recovery scheme has been implemented to recover the flue gas sensible heat by a heat-pipe heat exchanger.

Heat-pipe heat exchanger plays an important role in enhancing the performance of various industrial processes [1-3] for different kinds of purposes. In this heat recovery plan, the recovered energy is utilized to preheat the fuel gas used for hot stove combustion. The main purposes are to improve the thermal efficiency of the system as well as to reach the sustainable $\mathrm{CO}_{2}$ emission reduction throughout the hot blast generating process. In this work, the performance of the heat-pipe heat exchanger is analyzed and the efficiency improvement of the hot blast air generating system by waste heat recovery is investigated. Moreover, the benefits of energy saving and $\mathrm{CO}_{2}$ reduction by operation of the heat recovery system are explored. 


\section{Waste heat recovery system}

Fig. 2 illustrates the schematic diagram of the heat-pipe heat exchanger, which is categorized as a counter-flow gas-to-gas heat exchanger consisting of two ducts with a common wall. The evaporation section of the heat pipes is arranged in the lower duct for the exhausted flue gas to flow through, and the condensation section of the heat pipes is arranged in the upper duct for the BFG to flow through. With the joint operation of the heat-pipe heat exchanger, the flue gas exhausted from the hot stoves is fed into the heat-pipe heat exchanger before discharging to the atmosphere via the stack. This system is composed of 5520 heat pipes arranged in 92 rows. The detailed physical parameters are presented in Table 1.

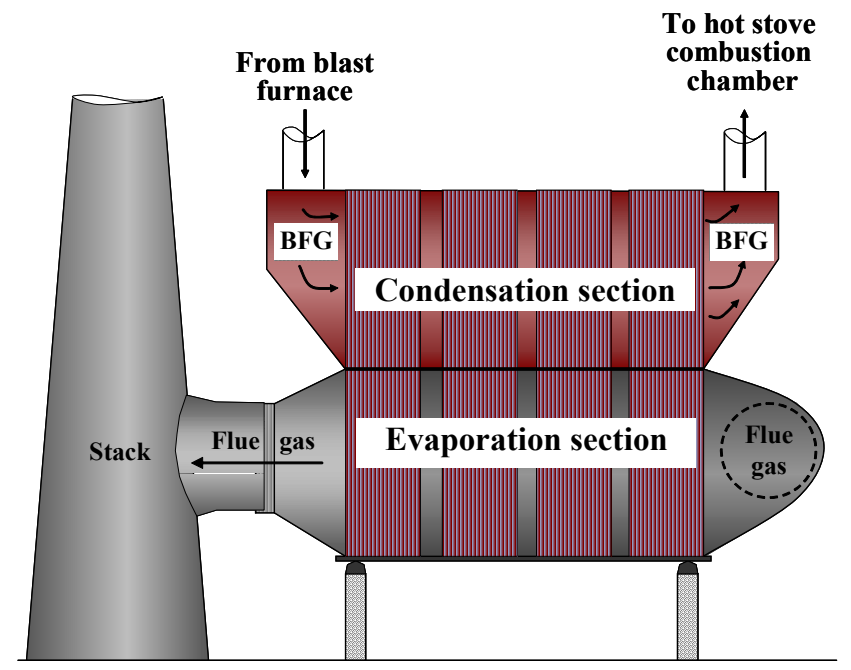

Figure 2: Schematic diagram of the heat-pipe heat exchanger.

Table 1: $\quad$ Physical parameters of the heat-pipe heat exchanger.

\begin{tabular}{||l|l||}
\hline Physical dimension & $10,525 \mathrm{~mm} \times 6,000 \mathrm{~mm} \times 8,540 \mathrm{~mm}$ \\
\hline Physical dimension of single heat pipe & $\varnothing 54 \mathrm{~mm} \times 9643 \mathrm{~mm}$ \\
\hline Tube bundle arrangement & Inline \\
\hline Total number of heat pipes & 5,520 \\
\hline Pitch(Traverse / Longitudinal) & $67.5 \mathrm{~mm} / 67.5 \mathrm{~mm}$ \\
\hline Working fluid & Water \\
\hline
\end{tabular}

\section{Results and discussion}

Experiments were carried out in the hot stoves of the No.2 Blast Furnace in CSC to explore the waste heat recovery effect on the efficiency of the hot blast generating process. In order to get further insight into the energy recycling 
process, the field performance of the heat-pipe heat exchanger is firstly investigated. Then, the performance evaluation method for the hot blast generating system is proposed and used to analyze its efficiency under various operation conditions. Finally, the annual benefits of energy saving and $\mathrm{CO}_{2}$ reduction by operation of the heat recovery system are explored

\subsection{Performance of the heat recovery system}

The hot blast generating system is operated with four hot stoves. In general, they are operated with fixed cycle time. The cycle time for the on-gas and onblast cycle is 50 and 60 minutes, respectively. The period for stove change is around 10 minutes. To keep stable hot blast air supply to blast furnace, the system is controlled in a way that two of the four hot stoves are in the on-blast operation mode all the time. Correspondingly, three typical operation conditions were selected and presented in Table 2 to investigate the relation between flue gas head load and heat recovery performance of the heat-pipe heat exchanger.

Table 2: $\quad$ Performance test results of the waste heat recovery system.

\begin{tabular}{||l|l|r|r|r||}
\hline \multicolumn{2}{|l|}{ Operation condition } & \multicolumn{1}{|c|}{1} & \multicolumn{1}{c|}{2} & \multicolumn{1}{c|}{3} \\
\hline \multirow{4}{*}{ Flue gas } & Volume flow rate $\left(\mathrm{Nm}^{3} / \mathrm{h}\right)$ & 141,016 & 201,190 & 253,582 \\
\cline { 2 - 5 } & Density $\left(\mathrm{kg} / \mathrm{m}^{3}\right)$ & 1.43 & 1.43 & 1.43 \\
\cline { 2 - 5 } & Specific heat $(\mathrm{kJ} / \mathrm{kg}-\mathrm{K})$ & 1.05 & 1.05 & 1.05 \\
\cline { 2 - 5 } & Inlet temperature $\left({ }^{\circ} \mathrm{C}\right)$ & 261 & 263 & 264 \\
\cline { 2 - 5 } & Outlet temperature $\left({ }^{\circ} \mathrm{C}\right)$ & 132 & 123 & 124 \\
\cline { 2 - 5 } & Flue gas sensible heat $(\mathrm{kW})$ & 13,851 & 19,988 & 25,035 \\
\hline \multirow{5}{*}{ BFG } & Volume flow rate $\left(\mathrm{Nm}^{3} / \mathrm{h}\right)$ & 81,429 & 144,791 & 175,291 \\
\cline { 2 - 5 } & Density $\left(\mathrm{kg} / \mathrm{m}^{3}\right)$ & 1.36 & 1.35 & 1.36 \\
\cline { 2 - 5 } & Specific heat $(\mathrm{kJ} / \mathrm{kg}-\mathrm{K})$ & 1.04 & 1.04 & 1.04 \\
\cline { 2 - 5 } & Inlet temperature $\left({ }^{\circ} \mathrm{C}\right)$ & 24 & 21 & 22 \\
\cline { 2 - 5 } & Outlet temperature $\left({ }^{\circ} \mathrm{C}\right)$ & 6,894 & 11,548 & 13,864 \\
\cline { 2 - 5 } & Heat recovery rate $(\mathrm{kW})$ & 49.8 & 57.8 & 55.4 \\
\hline \multirow{2}{*}{ Heat recovery efficiency $(\%)$} & & & 223 \\
\hline
\end{tabular}

The definitions for heat recovery rate and heat recovery efficiency [4] calculated in Table 3 are defined in Equation (1) and Equation (2).

Heat recovery rate $(\mathrm{kW})=\dot{\mathrm{m}}_{\mathrm{BFG}} \times \mathrm{c}_{\mathrm{p}, \mathrm{BFG}} \times\left(\mathrm{T}_{\mathrm{BFG}, \text { out }}-\mathrm{T}_{\mathrm{BFG}, \text { in }}\right)$

Heat recovery efficiency $(\%)=\frac{\dot{\mathrm{m}}_{\mathrm{BFG}} \times \mathrm{c}_{\mathrm{p}, \mathrm{BFG}} \times\left(\mathrm{T}_{\mathrm{BFG}, \text { out }}-\mathrm{T}_{\mathrm{BFG}, \text { in }}\right) \times 100}{\dot{\mathrm{m}}_{\mathrm{FLUE}} \times \mathrm{c}_{\mathrm{p}, \mathrm{FLUE}} \times\left(\mathrm{T}_{\mathrm{FLUE}, \text { in }}-273.15\right)}$ 
Table 2 depicted the heat recovery rate increased with an increase of the flue gas sensible heat within the test conditions. However, the outlet temperatures of the BFG showed an opposite trend. In accordance with the energy conservation relation between the BFG and flue gas, the temperature enhancement of the $\mathrm{BFG}$ is proportional to the energy that is absorbed by per unit volume of BFG. For operation condition 1,2 and 3 , it was $305.5 \mathrm{~kJ} / \mathrm{Nm}^{3}, 287.1 \mathrm{~kJ} / \mathrm{Nm}^{3}$ and $284.7 \mathrm{~kJ} / \mathrm{Nm}^{3}$, respectively. Therefore, the outlet temperatures of the BFG decreased with an increase in the heat load supplied from the flue gas. Regarding the heat recovery efficiency, Table 2 indicated that it first increased from $49.8 \%$ to $57.8 \%$ when flue gas sensible heat increased from $13,851 \mathrm{~kW}$ to $19,988 \mathrm{~kW}$, then it decreased slightly to $55.4 \%$ when the flue gas sensible heat further increased to $25,035 \mathrm{~kW}$. The phenomena implicated that the heat-pipe heat exchanger could be operated in a higher efficiency when the heat load is close to $20,000 \mathrm{~kW}$.

\subsection{Thermal efficiency of the hot blast air generating process}

The thermal efficiency of the hot blast air generating system is defined as the ratio of net energy increase in the blast air and the energy fed into the hot stoves. The total energy fed into the hot stoves is the sum of the chemical energy of the fuel gas (BFG enriched with $\mathrm{COG}$ ) and the sensible heat of the fuel gas and the combustion air. The calculation formulae $[5,6]$ can be expressed as follows.

$$
\begin{gathered}
\eta_{\mathrm{TH}}=\frac{\dot{\mathrm{Q}}_{\mathrm{BA}}}{\dot{\mathrm{Q}}_{\mathrm{BFG}}+\dot{\mathrm{Q}}_{\mathrm{COG}}+\dot{\mathrm{Q}}_{\text {cair }}} \\
\dot{\mathrm{Q}}_{\mathrm{BA}}=\dot{\mathrm{m}}_{\mathrm{HB}} \cdot\left(\mathrm{C}_{\mathrm{p}, \text { air }} \cdot \mathrm{T}_{\mathrm{HB}}-\mathrm{C}_{\mathrm{p}, \text { air }} \cdot \mathrm{T}_{\mathrm{CB}}\right) \\
+\dot{\mathrm{m}}_{\mathrm{HB}} \cdot \frac{\mathrm{AH}}{\rho_{\mathrm{H}_{2} \mathrm{O}}}\left(\mathrm{C}_{\mathrm{p}, \mathrm{H}_{2} \mathrm{O}} \cdot \mathrm{T}_{\mathrm{HB}}-\mathrm{C}_{\mathrm{p}, \mathrm{H}_{2} \mathrm{O}} \cdot \mathrm{T}_{\mathrm{CB}}\right) \\
\dot{\mathrm{Q}}_{\mathrm{BFG}}=\dot{\mathrm{m}}_{\mathrm{BFG}} \cdot \mathrm{H}_{\mathrm{BFG}}+\dot{\mathrm{m}}_{\mathrm{BFG}} \cdot \mathrm{C}_{\mathrm{p}, \mathrm{BFG}} \cdot \mathrm{T}_{\mathrm{BFG}} \\
\dot{\mathrm{Q}}_{\mathrm{COG}}=\dot{\mathrm{m}}_{\mathrm{COG}} \cdot \mathrm{H}_{\mathrm{COG}}+\dot{\mathrm{m}}_{\mathrm{COG}} \cdot \mathrm{C}_{\mathrm{p}, \mathrm{COG}} \cdot \mathrm{T}_{\mathrm{COG}} \\
\dot{\mathrm{Q}}_{\text {cair }}=\dot{\mathrm{m}}_{\text {air }} \cdot\left(\mathrm{C}_{\mathrm{p}, \text { air }}+\omega \cdot \mathrm{C}_{\mathrm{p}, \mathrm{H}_{2} \mathrm{O}}\right) \cdot \mathrm{T}_{\text {cair }}
\end{gathered}
$$

Table 3 presented the field test results of the hot blast generating system at two different operation conditions, CASE 1 and CASE 2. The duration for each test was 24 hours. The hot blast outlet temperature was set to be $1155^{\circ} \mathrm{C}$ for both cases. The main purpose of the tests was to explore the fuel gas preheating effect on the thermal efficiency of the hot blast generating system. As shown in 
Table 3, the inlet temperature of the BFG was $30^{\circ} \mathrm{C}$ in CASE 1 , in which the waste heat was not recycled in the hot blast generating process. With the operation of the heat-pipe heat recovery system, the BFG was preheated to $231{ }^{\circ} \mathrm{C}$ in CASE 2. Under this operation condition, $12,542 \mathrm{~kW}$ of the hot stove waste heat was recovered through the heat recovery system.

Based on the formulae described above, the calculations depicted the process efficiency of the entire hot blast generating system for CASE 1 and CASE 2 was $75.6 \%$ and $78.7 \%$, respectively. This result revealed that the energy consumed in the generating process to enhance the blast air temperature decreased form $2.008 \mathrm{~kJ} / \mathrm{Nm}^{3}-{ }^{\circ} \mathrm{C}$ to $1.893 \mathrm{~kJ} / \mathrm{Nm}^{3}-{ }^{\circ} \mathrm{C}$, indicating that the energy saving achieved by fuel gas preheating was $0.115 \mathrm{~kJ} / \mathrm{Nm}^{3}-{ }^{\circ} \mathrm{C}$.

Table 3: $\quad$ Field performance of the hot blast generating system.

\begin{tabular}{|c|c|c|c|c|}
\hline \multicolumn{3}{|c|}{ Item } & CASE 1 & CASE 2 \\
\hline \multirow{13}{*}{$\begin{array}{c}\text { Operational } \\
\text { conditions }\end{array}$} & \multicolumn{2}{|c|}{ Environment temperature $\left({ }^{\circ} \mathrm{C}\right)$} & 29 & 20 \\
\hline & \multicolumn{2}{|c|}{ Blast air volume flow rate $\left(\mathrm{Nm}^{3} / \mathrm{hr}\right)$} & 299,134 & 302,142 \\
\hline & \multicolumn{2}{|c|}{ Inlet temperature $\left({ }^{\circ} \mathrm{C}\right)$} & 230 & 219 \\
\hline & \multicolumn{2}{|c|}{ Outlet temperature $\left({ }^{\circ} \mathrm{C}\right)$} & 1,155 & 1,155 \\
\hline & \multicolumn{2}{|c|}{ Combustion air volume flow rate $\left(\mathrm{Nm}^{3} / \mathrm{hr}\right)$} & 129,780 & 112,802 \\
\hline & \multicolumn{2}{|c|}{ COG temperature $\left({ }^{\circ} \mathrm{C}\right)$} & 40 & 30 \\
\hline & \multicolumn{2}{|c|}{ COG volume flow rate $\left(\mathrm{Nm}^{3} / \mathrm{hr}\right)$} & 8,827 & 2,671 \\
\hline & \multicolumn{2}{|c|}{ COG low heating value $\left(\mathrm{kJ} / \mathrm{Nm}^{3}\right)$} & 16,765 & 17,673 \\
\hline & \multicolumn{2}{|c|}{ BFG temperature } & 30 & 231 \\
\hline & \multicolumn{2}{|c|}{ BFG volume flow rate $\left(\mathrm{Nm}^{3} / \mathrm{hr}\right)$} & 123,116 & 147,826 \\
\hline & \multicolumn{2}{|c|}{ BFG low heating value $\left(\mathrm{kJ} / \mathrm{Nm}^{3}\right)$} & 3,224 & 3,255 \\
\hline & \multicolumn{2}{|c|}{ Relative humidity of the atmosphere (\%) } & 83 & 72 \\
\hline & \multicolumn{2}{|c|}{ Absolute humidity of the blast air $\left(\mathrm{g} / \mathrm{Nm}^{3}\right)$} & 27 & 16 \\
\hline \multirow{4}{*}{$\begin{array}{c}\text { Performance } \\
\text { analysis }\end{array}$} & \multirow[b]{2}{*}{ Energy input } & Sensible heat $(\mathrm{kW})$ & $2,943.4$ & $1,956.8$ \\
\hline & & Chemical energy $(\mathrm{kW})$ & $151,351.2$ & $146,750.4$ \\
\hline & \multicolumn{2}{|c|}{ Hot blast sensible heat $(\mathrm{kW})$} & $116,664.4$ & $117,104.2$ \\
\hline & \multicolumn{2}{|l|}{ Efficiency (\%) } & 75.6 & 78.7 \\
\hline
\end{tabular}

In addition to energy saving, the change in BFG and COG depletion rates indicated that the fuel gas preheating also leaded to the reduction of the enrichment gas consumption. In CASE 2 , only $8.9 \%$ of the energy supplied to the hot stoves was contributed by the COG, whereas it was $27.2 \%$ in CASE 1 .

A parametric study by varying the hot blast outlet temperatures was made to examine the operation characteristics of the system under various hot blast temperature levels. The temperature range of the tests was between $1130^{\circ} \mathrm{C}$ to $1155^{\circ} \mathrm{C}$. As shown in Fig. 3, the calculation results depicted that the thermal efficiency of the hot blast generating system kept above $78 \%$ with the operation of the waste heat recovery system. 


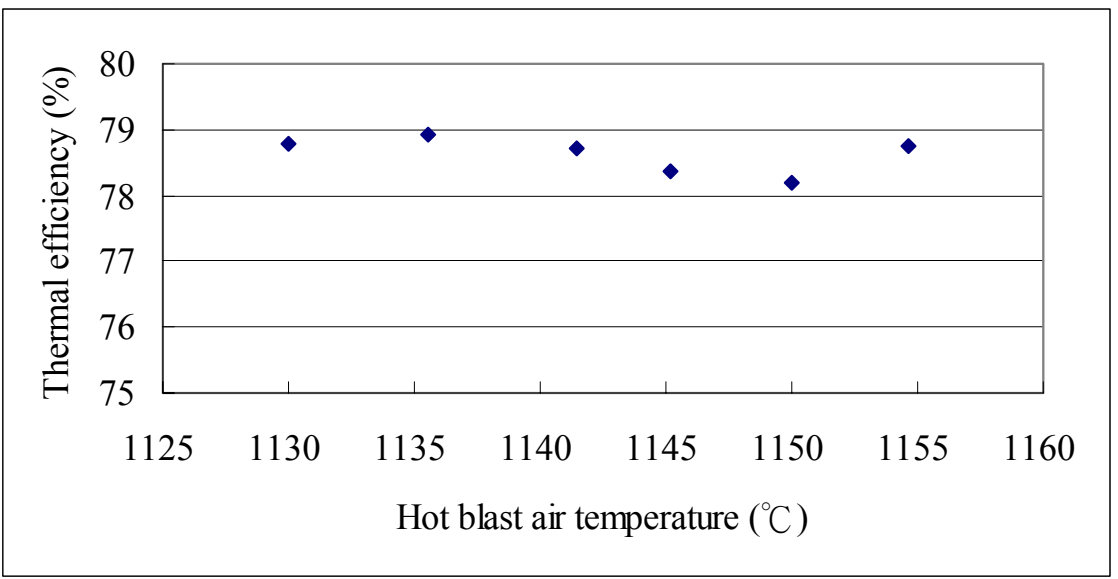

Figure 3: Thermal efficiency of the hot blast generating system at various hot blast air temperatures.

\subsection{Energy saving and $\mathrm{CO}_{2}$ reduction}

In accordance with the operation records, the major difference observed in operation conditions was the fuel gas consumption rate of the hot stoves. Furthermore, to overcome the additional pressure loss and maintain the same BFG feeding pressure for hot stove combustion, the top pressure recovery turbine, the TRT, power generation rate was reduced. Table 4 summarized the breakdown of energy savings and $\mathrm{CO}_{2}$ reduction per year. The economic evaluations were referred to US dollars. These calculations were performed based on the following assumptions:

1. Oil price: $0.34 \mathrm{USD} / l$

2. Cost of electricity: $0.045 \mathrm{USD} / \mathrm{kWh}$

3. $\mathrm{CO}_{2}$ emission conversion factors: $0.66 \mathrm{~kg} / \mathrm{kWh}$

4. Operation hours: $7,884 \mathrm{~h} /$ year

5. Hot blast air outlet temperature: $1,155^{\circ} \mathrm{C}$.

As presented in Table 4, the advantage of operating the heat recovery system is evident in the fuel consumption reduction by $822 \mathrm{l} / \mathrm{h}$ on an oil equivalent basis. However, the TRT power generation rate was reduced by $621 \mathrm{~kW}$ and some additional power needed to be consumed for fan operation. The total economic benefits for energy saving can exceed 1.9 million US dollars per year. In the mean time, the $\mathrm{CO}_{2}$ emission can have a reduction of 15,254 ton/year. 
Table 4: Annual energy saving and $\mathrm{CO}_{2}$ reduction analyses.

\begin{tabular}{||l|c|c|c|c||}
\hline \multirow{2}{*}{ Items } & Operation conditions & \multicolumn{2}{c||}{ Benefits } \\
\cline { 2 - 5 } & Before & After & $\begin{array}{c}\text { Savings } \\
\text { (USD /year) }\end{array}$ & $\begin{array}{c}\mathrm{CO}_{2} \\
\text { reduction } \\
\text { (ton/year) }\end{array}$ \\
\hline $\begin{array}{l}\text { Fuel consumption in oil } \\
\text { equivalent basis }(l / \mathrm{h})\end{array}$ & 14,393 & 13,571 & $2,178,278$ & 19,115 \\
\hline $\begin{array}{l}\text { TRT power generation } \\
(\mathrm{kW})\end{array}$ & 10,688 & 10,067 & $-219,518$ & $-3,230$ \\
\hline $\begin{array}{l}\text { Additional power } \\
\text { consumption }(\mathrm{kWh} / \text { year) }\end{array}$ & - & 956,081 & $-42,879$ & -631 \\
\hline \hline \\
Total
\end{tabular}

\section{Conclusion}

Waste heat recovery is an efficient way to reach the aim of energy saving and $\mathrm{CO}_{2}$ emission reduction through the energy recycling process. In this article, the effect of fuel gas preheating on the thermal efficiency of the hot blast generating system is investigated. Experimental results revealed that the efficiency of the hot blast generating process was increased from $75.6 \%$ to $78.7 \%$. Accordingly, the energy spent for producing the hot blast air decreased by $0.115 \mathrm{~kJ} / \mathrm{Nm}^{3}{ }^{\circ} \mathrm{C}$. In the meantime, the fuel gas preheating leaded to the reduction of the enrichment gas consumption. According to the test results, the advantage of operating the heat recovery system was evident in the reduction of fuel gas depletion rate by $822 \mathrm{l} / \mathrm{h}$ on an oil equivalent basis. The annual energy saving over 1.9 million US dollars and the $\mathrm{CO}_{2}$ reduction 15,000 ton/year can be achieved.

\section{Nomenclature}

AH: Absolute humidity of the blast air $\left(\mathrm{g} / \mathrm{Nm}^{3}\right)$

$\mathrm{C}_{\mathrm{p}}$ : Specific heat, $(\mathrm{kJ} / \mathrm{kg}-\mathrm{K})$

$\mathrm{H}$ : Low heating value of the fuel gas $(\mathrm{kJ} / \mathrm{kg})$

$\dot{\mathrm{m}}$ : Mass flow rate, $(\mathrm{kg} / \mathrm{h})$

$\dot{\mathrm{Q}}$ : Energy flow, $(\mathrm{kJ} / \mathrm{h})$

$\mathrm{T}:$ Temperature $\left({ }^{\circ} \mathrm{C}\right)$

$\rho: \quad$ Density $\left(\mathrm{g} / \mathrm{Nm}^{3}\right)$

$\omega$ : Humidity ratio of the combustion $\operatorname{air}(\mathrm{kg} / \mathrm{kg})$. 


\section{Subscripts}

Air: Combustion air

BA : Blast air

BFG: Blast furnace gas

CB: Cold blast air

COG: Coke oven gas

FLUE: Flue gas

HB: Hot blast air

In: Inlet condition

Out: Outlet condition.

\section{References}

[1] Pattnapong Khantha and Pradit Terdtoon, "Heat pipe air-preheater and its application in gypsum drying", Proceedings of the $11^{\text {th }}$ Industrial Heat Pipe Conference, Tokyo, Japan, 1999.

[2] Alessandro Franco and Alessandro Russo, "Combined cycle plant efficiency increase based on the optimization of the heat recovery steam generator operating parameters", International Journal of Thermal Sciences, Vol. 41, pp. 843-859, 2002.

[3] L. L. Vasiliev, "Heat pipes in modern heat exchanger", Applied Thermal Engineering, Vol. 25, pp. 1-19, 2005.

[4] P. H. Wang and P. H. Lin, "Recovering Hot Stove Waste Heat by Heat Pipes", 2006 SEAISI Conference, Philppine, Cebu, 2006.

[5] Gordon J. Van Wylen and Richard E. Sonntag, "Fundamentals of classic thermodynamics", Third Edition, John Wiley \&Sons, Inc., 1985.

[6] Wilbert F. Stoecker and Jerold W. Jones, "Refrigeration \& Air Conditioning", Second Edition, McGraw-Hill, 1982. 